Kirsten Palm

Høgskolen i Oslo og Akershus

Else Ryen

Universitetet i Oslo

\title{
Vurdering av andrespråksinnlærere - en utfordring i skolen
}

\section{Sammendrag}

Vurdering av andrespråkselevers språkkompetanse og språkutvikling er en sentral del av lereres arbeid, og forskning har vist at dette er en utfordring for skolene. Det er stor variasjon i vurderingsformer, og skolene mangler ofte vurderingskompetanse. På bakgrunn av dette utarbeidet Utdanningsdirektoratet i 2007 vurderingsverktøyet Kartleggingsmateriell. Språkkompetanse i grunnleggende norsk for språklige minoriteter. Materiellet er utarbeidet blant annet med referanse til Common European Framework of Reference for Languages (CEFR). I artikkelen redegjør vi for en undersøkelse der målet var å finne ut hvorvidt dette kartleggingsmateriellet er hensiktsmessig for å vurdere andrespråkselevers språkkompetanse.

Dataene er innhentet gjennom kasusstudier ved tre grunnskoler, der vi intervjuet skoleledelse og larere samt observerte kartleggingssituasjoner og klasseromsundervisning. Kasusstudiene ble senere fulgt opp av to spørreundersøkelser, én til de samme skolene, og én til et større antall skoler for å få bredere innsikt i kartleggingspraksis og skolers oppfatninger av denne formen for vurdering.

Undersøkelsen viser at flere av informantene mener verktøyet kan bidra til mer tilpasset og systematisk andrespråkopplæring og bedre vurdering av andrespråkselevenes språkkompetanse. Samtidig er det utfordringer knyttet til å bruke vurderingsverktøyet, dette skyldes blant annet mangelfull kompetanse $i$ skolen når det gjelder andrespråkstilegnelse og vurdering av elevenes språkkompetanse.

Det er ikke tidligere forsket på bruk av et slikt konkret kartleggingsverktøy $i$ norsk grunnskole. Undersøkelsen kan gi et bidrag til økt kunnskap om vurdering av andrespråkskompetanse og tilpasset undervisning for andrespråksinnlcerere. 


\section{Innledning}

I all andrespråksopplæring i skolen vil vurdering av elevenes språkkompetanse og språkutvikling være en del av lærerens arbeid. En utfordring for skolen er å finne fram til hensiktsmessige vurderingsformer for elever i en språklæringsfase. Det er også vesentlig at lærere har kunnskaper om andrespråkslæring. De må dessuten være i stand til kritisk å vurdere ulike former for tester og vurdering og til å fortolke resultater slik at andrespråkselevene får gode opplæringstilbud.

I norsk grunnskole brukes en rekke ulike tester for å vurdere språkkompetansen til minoritetsspråklige elever. Noen av testene er utprøvd og brukes av flere skoler, andre er selvlaget ved den enkelte skole. Et kjennetegn ved testene er at de fokuserer på ord og begreper eller leseferdigheter. Det vil si at de ikke tar hensyn til elevens totale språklige potensial, blant annet fokuseres det lite på muntlige ferdigheter, noe som er helt sentralt når det gjelder andrespråksinnlærere. Testene tar heller ikke sikte på å vurdere elevenes språklige utvikling over tid. Testmateriell brukes ofte svært tilfeldig, slik det blant annet ble avdekket i en undersøkelse i 2006 (Rambøll Management). Undersøkelsen viste dessuten mangelfull kompetanse på skolenivå og hos den enkelte lærer både til å gjennomføre tester og til å fortolke testresultater. Dette er noe av bakgrunnen for at Utdanningsdirektoratet i 2007 fikk utarbeidet vurderingsverktøyet Kartleggingsmateriell. Språkkompetanse i grunnleggende norsk for språklige minoriteter (Utdanningsdirektoratet, 2007). Materiellet er utarbeidet blant annet med referanse til Common European Framework of Reference for Languages (CEFR) (Council of Europe, udatert).

I skoleåret 2009-2010, etter at flere skoler hadde brukt kartleggingsmateriellet over to år, ønsket vi å foreta en undersøkelse for å finne ut hvorvidt dette materiellet er hensiktsmessig for å vurdere andrespråkselevers språkkompetanse. Vi foretok derfor en kasusstudie ved tre grunnskoler. Denne studien ble fulgt opp to år senere gjennom en mindre spørreskjemaundersøkelse. I mars 2013 gjennomførte vi en spørreundersøkelse ved et større antall skoler for å få bredere innsikt i kartleggingspraksis og skolers oppfatninger av denne formen for vurdering.

I artikkelen gir vi først en kort redegjørelse for den skolepolitiske rammen som Kartleggingsmateriell. Språkkompetanse i grunnleggende norsk for språklige minoriteter må ses i sammenheng med. Vi gir også en presentasjon av materiellet. Testing og vurdering av andrespråksferdigheter settes inn i en teoretisk sammenheng, og vi sammenligner verktøyet med andre vurderingsverktøy som brukes for andrespråkselever i norsk skole. Deretter redegjør vi for metodene vi har valgt for undersøkelsen, før vi presenterer funnene våre og drøfter resultatene av undersøkelsen. 
Kartlegging av grunnleggende kompetanse i norsk

\section{Skolepolitiske rammer}

Språktesting og vurdering finner alltid sted innenfor en utdannings- og skolepolitisk kontekst, og vurdering av andrespråksferdigheter i norsk skole må ses i en videre sammenheng knyttet til lovgiving og til skolens læreplaner.

Elever som har et annet morsmål enn norsk eller samisk har en lovfestet rett til særskilt opplæring i norsk inntil de har tilstrekkelige ferdigheter til å følge ordinær undervisning. Det heter også at de om nødvendig har rett til morsmålsopplæring, tospråklig fagopplæring eller begge deler (Opplæringslova § 2-8 for grunnskolen, § 3-12 for videregående opplæring). Undervisningen kan bli gjennomført ut fra en tilpassing av den ordinære læreplanen i norsk eller etter en egen læreplan, Lcreplan i grunnleggende norsk for språklige minoriteter (Utdanningsdirektoratet a, udatert). Beslutningen om å gi særskilt norskopplæring skal gis som et individuelt vedtak (jf. Forvaltningsloven $\S 2$ ). Ofte har det vært mangelfulle rutiner for kartlegging, og det har ikke vært noen enhetlig praksis i hva slags hjelpemidler skolene har brukt for vurdering (jf. f.eks. Rambøll Management, 2006; Vibe m.fl., 2009.) I 2009 fikk opplæringsloven en ny bestemmelse som ga skolene plikt til å kartlegge elevens norskferdigheter før det ble fattet vedtak om særskilt norskopplæring. Kartlegging må også følges opp både som et redskap for å gi tilpasset undervisning og for å kunne vurdere om en elev har god nok norskkompetanse til å gå over til ordinær undervisning. Det er imidlertid fortsatt ingen bestemte retningslinjer for hva slags kartleggingsverktøy som skal brukes eller hvordan vurderingene skal gjennomføres, selv om Kunnskapsdepartementet har anbefalt å bruke Kartleggingsmateriell. Språkkompetanse i grunnleggende norsk for språklige minoriteter (Ot. Prop.55, 2008-09). I en spørreundersøkelse fra Utdanningsdirektoratet i 2009 framgikk det at noe under halvparten av skolene i undersøkelsen brukte dette materiellet (Vibe m.fl. 2009, s.39). Praksis er trolig fortsatt svært varierende.

\section{Kartleggingsmateriell, s. grunnleggende norsk for språklige minoriteter}

Det aktuelle kartleggingsmateriellet er i noen grad influert av to språkpermer som var utviklet tidligere innen det norske utdanningssystemet, Europeisk språkperm for voksne innvandrere (Utdanningsdirektoratet b, udatert) og Europeisk språkperm for 13-18 år (Fremmedspråksenteret udatert). Disse språkpermene er laget på grunnlag av European Language Portfolio (ELP), som primært har pedagogiske formål (jf. Figueras m.fl. 2005, s.266). Kartleggingsmateriellet er dermed forbundet med ELP som med 118 utgaver er validert av Europarådet (Council of Europe, 2011) og kan anses som del av et globalt instrument for vurdering av språk. Men Kartleggingsverktøy for grunnleggende norsk er ikke skåret over helt den samme lesten. Kompetansemålene er knyttet opp mot Lereplan i grunnleggende norsk for elever fra språklige minoriteter og er mer spesifikt tilpasset en gruppe av elever som er andrespråksinnlærere. 
Materiellet er aldersuavhengig, det vil si at kompetansemålene er formulert slik at de skal kunne anvendes for elever på ulike trinn i utdanningsløpet.

Kartleggingsmateriellet består av tre deler: en språkbiografi, et kartleggingsverktøy og elevens språkmappe. Språkbiografien inneholder to skjemaer, ”Min språkbiografi” og "Min språklæring”. Intensjonen er at lærer og elev samarbeider om utfylling av skjemaene, eleven får da mulighet til blant annet å fortelle om sin kompetanse på morsmålet og eventuelt andre språk, og det blir tydelig at elevens bakgrunnskunnskaper tillegges verdi. Utvikling av elevens andrespråkskompetanse vurderes ved hjelp av kartleggingsverktøyet som er den mest omfattende delen av materiellet. Verktøyet består av to deler, en del som inneholder beskrivelser av ferdigheter på tre nivåer og en del med kompetansemål formulert som "eleven kan"-utsagn. Verktøyet er inndelt i seks hovedområder, s. lytte, tale, lese, skrive, språklcring og språk og kultur. "Eleven kan"-utsagnene viser hva elevene mestrer med mye hjelp, hva de mestrer med litt hjelp og hva de mestrer uten hjelp innenfor de ulike hovedområdene og synliggjør på den måten elevens progresjon. Det er meningen at lærerne skal vurdere om ulike kompetansemål er nådd, men vurderingen skal foregå i samarbeid med eleven. Både dette og at det gjennom de ulike hovedområdene fokuseres på en helhetlig språkkompetanse, er ikke vanlig vurderingspraksis i norsk skole. Vi kommer tilbake til dette i neste avsnitt.

\section{Vurdering av andrespråksinnlærere}

\section{Ulike prøveformer i norsk skole}

Norske skoleelever deltar i en lang rekke standardiserte tester, kartleggingsprøver og nasjonale prøver i lesing (Utdanningsdirektoratet, udatert) og internasjonale undersøkelser som PISA og PIRLS. Alle disse har et enspråklig utgangspunkt, og den primære målgruppen for prøvene er elever som har det aktuelle språk som førstespråk. De fleste minoritetsspråklige elever i Norge deltar på slike prøver, og flere analyser av norske data viser at de som gruppe skårer lavere enn majoritetsspråklige elever (Wagner, 2004; Hvistendahl \& Roe, 2004; Hvistendahl \& Roe, 2009). Men elever som ikke har førstespråkskompetanse i norsk, deltar ikke på like vilkår med majoriteten av elevene. Testene de må gjennomføre, tar ikke hensyn til deres tospråklighet, og også når testene er konstruert for å prøve elever i ulike ferdigheter i norsk språk, gjennomfører andrespråksinnlærere testene under de samme betingelser som de øvrige elevene.

I artikkelen "Assessing multilingual competences: Adopting Multilingual Competencies" peker Shohamy (2011) på hvor urettferdig det er å sammenligne grupper som ikke har sammenlignbare betingelser. Hun refererer til en studie hun gjennomførte ti år tidligere der resultatene fra minoritetsgruppene var veldig svake, og ved ettertanke sier hun: 
These types of comparisons are of low validity and fairness as the students do not have the appropriate channel to demonstrate their academic knowledge. Such results are likely to have effects on their identity, confidence and self concept. (Shohamy, 2011, s.5)

I tillegg til å vurderes ut fra slike standardiserte prøver som nevnt ovenfor, måles andrespråkselever også ut fra lokale tester utarbeidet ved enkeltskoler eller gjennom enkelte prøver som brukes av et større antall skoler. Slike tester kan appellere til lærere ved at de er enkle å administrere, og det tar kort tid å gjennomføre dem. En prøve som har vært brukt i relativt stort omgang siden den ble utarbeidet i 1991, er Daglignorsk-prøven (Arbeid med ord 2014). Vi skal se litt nærmere på den fordi den illustrerer kritiske forhold knyttet til vurdering av andrespråkselever. Prøven svært avgrenset i omfang, og den sies å skulle måle ord, innholdsforståelse og kommunikative ferdigheter for elever fra 1. -10. trinn. Et problem ved en test av denne typen er at den lover langt mer enn den kan holde. I alt måles forståelsen og bruken av 75 ord ved hjelp av oppgaver knyttet til to ark med tegninger som framstiller en rekke dagligdagse gjøremål. Kommunikative ferdigheter skal måles gjennom svar på 25 spørsmål av typen: "Hva tror du hun har i kofferten?", "Hvorfor må vi spise frokost?" "Hvorfor er det dører på et hus?" Dette omtales som grunnprøven. For hvert av trinnene 5-7 og 8-10 finnes i tillegg en svært enkel leseprøve på under en halv side. Prøven går ut på å peke ut hvilket av tre oppgitte ord som er riktig i henholdsvis seks og seksten enkle setninger, i tillegg skal høytlesing av tekstene bedømmes. For prøven angis det en prosentandel, identisk med antall riktige ord, for ulike mestringsgrader, og ut fra dette fastslås det om elever kan følge vanlig undervisning eller om de må ha ulike tilbud om andrespråksopplæring. Slike avgjørelser må en kunne fastslå at tas på svært sviktende grunnlag (jf. Hauge og Ryen, 1992).

En prøve av en annen karakter er Tospråklighetsprøven (TOSP) (Loona, 1995). Denne prøven var i første omgang utarbeidet til bruk ved Pedagogiskpsykologisk tjeneste (PPT), men brukes også ved flere skoler. Her prøves begrepsforståelse, ordforråd og leseferdigheter for elever fra 1.-5. trinn og 6.10. trinn. Den er utarbeidet på norsk og 21 andre språk, og den skal kunne måle elevenes ferdigheter også på morsmålet. Prøven vil da kunne si noe om en elevs utvikling på to språk og gi informasjon om hvilket språk eleven er sterkest i. Den brukes imidlertid ikke alltid på begge språkene. Begge prøvene nevnt over har vært brukt over lang tid og ble utarbeidet da skolen hadde andre læreplaner enn de som er i bruk i dag.

Et nytt materiell er Norsk som leringsspråk, utarbeidet ved PPT i Oslo til bruk på 1.-4. trinn. Dette er et læreplanorientert screeningsverktøy som er ment å gi en indikasjon på en elevs norskspråklige kompetanse knyttet opp mot læreplanen i norsk. Områdene som måles er begrepsdanning, ordforståelse og grammatikk (Oslo kommune, Utdanningsetaten, 2013). 
Felles for alle prøvene som er nevnt over, er at de er laget for å måle elevers ferdigheter på et gitt tidspunkt. Bortsett fra Tospråklighetsprøven spør ingen etter elevenes tidligere kunnskaper, og heller ikke denne prøven trekker inn elevenes bakgrunnskunnskaper, men en styrke ved denne prøven er at elever kan prøves i ord- og begrepskunnskap også på eget morsmål. En ulempe for minoritetselever er da at de sjelden får aktivert sin egen bakgrunn og sine kulturelle kunnskaper ved ulike tester og prøver, enten de brukes for alle elever i norsk skole eller det er prøver som er utarbeidet spesielt for andrespråkselever. Som McKay (2006, s.229) skriver, vil dette sannsynligvis ha negativ påvirkning på elevenes prestasjoner.

Kartleggingsmateriell. Språkkompetanse i grunnleggende norsk er også enspråklig, men det er et vurderingsmateriell, ikke en test, og det har derfor videre rammer. Det fokuserer både på muntlige og skriftlige ferdigheter, både reseptive og produktive. Dessuten omfatter det kompetanseområder som språklæring og språk og kultur. På den måten viser en kartlegging med dette verktøyet en større bredde i elevens språkkompetanse enn de tidligere nevnte prøvene. Det skal dessuten først og fremst brukes formativt som et verktøy for vurdering av elevenes kompetanse underveis i opplæringsløpet og for planlegging av undervisning. Dette må anses som en styrke ved et slikt verktøy. Materiellet har fellestrekk med det som kalles dynamisk kartlegging, der et av målene er å få innsikt i hvor mye hjelp barn og unge trenger for å løse en oppgave og for å kunne tilrettelegge for videre utvikling (Monsrud 2012, s.117). Det er imidlertid en utfordring at det ikke er et presist måleverktøy. Det krever derfor en annen type kompetanse blant lærere enn det en må ha for å gjennomføre en standardisert test. En utfordring er også at verktøyet ikke bare er tenkt brukt formativt, men også summativt siden det også skal kunne brukes for å vurdere elevers rett til særskilt norskopplæring, og det har dermed en administrativ funksjon. Dette kommer vi tilbake til nedenfor.

\section{Formål og kjennetegn ved ulike typer vurderingsformer}

Når det gjelder språkkartlegging og vurdering av elevers ferdigheter, kan man skille mellom administrative og pedagogiske formål. Pedagogiske formål vil primært være å fremme læring, mens administrative formål først og fremst er å rapportere om resultater til overordnede myndigheter, for eksempel i forbindelse med tildeling av midler til undervisningen (jf. McKay, 2006, s.21). Det kan også dreie seg om å plassere elever i ulike nivågrupper eller klasser (op.cit., s.23; Hyland 2003, s.214) De pedagogiske og de administrative formålene med vurdering kan til en viss grad overlappe, men det kan oppstå spenninger mellom disse to formålene, og administrative formål vil ofte overskygge de pedagogiske (Mc Kay, 2006, s.21). Det er for eksempel en kjent diskusjon hvordan utstrakt testing kan ha en "washback"-effekt på undervisningen, både positiv og negativ. En negativ effekt vil kunne være at lærere konsentrerer seg om områder som blir testet, i stedet for områder som ville gitt et større pedagogisk utbytte for elevene 
(Leung 2005, s.871; McKay, 2006, s.92). Elever risikerer å bli vurdert som potensielle testpoeng, mener van Lier, og advarer mot at et sterkt fokus på standarder og testing kan gå ut over kvaliteten på opplæringen (van Lier, 2004, s.6, 17). Backmann m.fl. (2010) drøfter blant annet hvorvidt undersøkelser som PISA kan føre til at skoler fokuserer for mye på individuelle prestasjoner, noe som kan gå på bekostning av felles prosesser i undervisningen som ikke minst de flerspråklige elevene har behov for.

Administrative tester vil som regel være normbaserte. Kartleggingsverktøyet for grunnleggende norsk derimot har likheter med det som kalles kriteriebaserte tester. Det vil si at det ikke foretas en sammenlikning og rangering av elevene, men at prestasjonene deres blir vurdert ut fra graden av måloppnåelse (Stokke m.fl., 2008, s.19), i dette tilfelle beskrivelser av språkferdigheter på et gitt nivå. Det innebærer at elevene kan arbeide mot måloppnåelse i sitt eget tempo, og en forsøker å lage individuelle språkprofiler for ulike språklige ferdigheter (Baker 2006, s.23). Ved normrelatert vurdering derimot vurderes og rangeres elevene i lys av andre elevers prestasjoner. De fleste storskalatestene som blir brukt i Norge, er normrelaterte, f.eks. den nasjonale leseprøven hvor elever på femte og åttende trinn deltar. Ved en slik test er det et mål å plassere kandidatene på en form for ordnet skala ut fra hva som er ansett for det typiske og gjennomsnittlige resultatet for aldersgruppa (Alderson m.fl., 1995, s.76; McNamara, 2000, s.63). Skolene og kommunene bruker ofte resultatene på slike prøver for å se sine egne resultater opp mot en nasjonal eller internasjonal norm.

Begge vurderingsformer har sine fordeler og ulemper. Normrelaterte tester er basert på empiriske data og er vanligvis lette å administrere. Som McNamara (op.cit.) påpeker, kan slike tester åpne for klart definerte ferdighetsnivåer, og spørsmål knyttet til validitet og reliabilitet kan undersøkes. En ulempe er imidlertid at de vanligvis fokuserer på avgrensede trekk ved språket som kan kvantifiseres og måles (jf. Holm \& Laursen, 2010, s.186). Leung (2005, s.871) peker på at ved konstruksjoner av tester er det i normeringsprosessen en tendens til at språklige minoritetsgrupper er underrepresentert. Dessuten utelates testelementer som har lav korrelasjon med den totale testskåren, og dette kan være deler der minoritetselever ville ha skåret bra. En annen ulempe er at slike tester ofte sammenligner tospråklige med enspråklige slik at normen blir den innfødte språkbrukeren. Slik (urettferdig) sammenligning kan unngås med kriterierelaterte tester eller kartleggingsmateriell. Gjennom denne formen for vurdering prøver en ofte å måle brede aspekter ved språket og kommunikativ kompetanse. Fokus er hva eleven mestrer, ikke feil og mangler. Dette kan lettere opprettholde motivasjonen hos innlærerne. En fordel ved slik vurdering er også at den kan gi læreren tilbakemeldinger som lett kan føre til konkrete tiltak i undervisningen (jf. Baker 2006, s.24 f). Men en svakhet er at beskrivelsene av språknivåene delvis kan være basert på subjektive antakelser og en mer generell oppfatning av andrespråksteori (Holm \& Laursen 2010, s.187), og bedømmernes kompetanse 
og samsvar eller mangel på samsvar mellom ulike bedømmere vil ha betydning for resultatene (McNamara, 2000).

Læreres andrespråkskompetanse er sentral også i den daglige undervisningen. Mye av vurderingen av elevenes språkkompetanse vil måtte foregå gjennom klasseromsbasert lærervurdering. Leung (2005) omtaler dette som den informasjonen lærere innhenter om elevers språkbruk i de ordinære klasseromsaktivitetene samt bruken av denne informasjonen i språkundervisningen - uten at informasjonen nødvendigvis skal kvantifiseres eller brukes til rapportering videre (op.cit., s.871). Slik vurdering har ifølge Leung (op.cit., s.885) blant annet den styrken at den er integrert i de ordinære undervisningsprosessene, og læreren kan gi direkte tilbakemeldinger til elevene.

\section{Utfordringer ved vurdering av andrespråkskompetanse i grunnskolen}

For å kunne vurdere andrespråkskompetanse er det en forutsetning at lærere har solide kunnskaper om unge elever generelt og om andrespråkslæring spesielt. De må kunne ta hensyn til spesielle kjennetegn og forutsetninger som er nødvendige i utviklingen og tilegnelsen av lese- og skriveferdigheter. McKay (2006, s.219) trekker fram at muntlig språkkompetanse i målspråket er én av tre nøkkelfaktorer for å oppnå gode lese- og skriveferdigheter i det nye språket. To andre sentrale faktorer for god skriftspråksutvikling dreier seg om hvorvidt elevene kan lese og skrive på morsmålet samt hva slags kulturell og faglig bakgrunnskunnskap de har. Lærere som skal vurdere andrespråkselever, må ha forståelse for betydningen av alle disse tre faktorene og hvordan de påvirker elevenes prestasjoner. Dessuten må man være klar over den sårbarheten som barn bringer med seg til opplærings- og vurderingssituasjoner (op.cit., s.24) og at også det følelsesmessige samspillet mellom eleven og læreren i en kartleggingssituasjon kan få konsekvenser for resultatet (jf. f.eks. Daugård, 2009).

Undersøkelser av kompetansen til lærere som underviser i grunnleggende norsk for språklige minoriteter (Rambøll Management, 2006; Danbolt m.fl., 2010) viser at de færreste lærere som har slik undervisning, har spesiell formell kompetanse i andrespråksopplæring. Det kan bety at de nettopp mangler den kompetansen som bl.a. McKay framhever at lærere bør ha i forbindelse med vurdering og kartlegging.

Vi kommer tilbake til hvilke synspunkter de skolelederne og lærerne vi intervjuet, har på kartlegging og lærerkompetanse. Men først vil vi gi en presentasjon av dataene våre.

\section{Datagrunnlag og metode}

For å få svar på spørsmålet om hvorvidt kartleggingsverktøyet er hensiktsmessig for å vurdere andrespråkselevers språkkompetanse, gjennomførte vi skoleåret 2009-2010 en kasusstudie på tre skoler i tre ulike kommuner. To av skolene var barneskoler, og én var en kombinert 1-0 skole, og henholdsvis 13\%, 23\% og $25 \%$ av elevene hadde andre førstespråk enn norsk. Et premiss for utvelgelsen 
av skolene var at de skulle ha brukt kartleggingsverktøyet over en lengre periode, slik at de hadde høstet praktiske erfaringer og hadde kunnet danne seg meninger om hvorvidt dette var et hensiktsmessig verktøy for kartlegging av elevers andrespråksferdigheter. Vi visste at ved den ene skolen var verktøyet tatt i bruk på initiativ fra lærere. De to andre skolene var pålagt av kommunen å bruke det. Andelen minoritetsspråklige elever ved de tre skolene kan sies å være representativt for et større antall skoler i Norge.

I kasusstudien deltok åtte lærere, fem skoleledere og 21 elever fra første til tiende trinn. Lærerne var lærere i norsk som andrespråk og/eller kontaktlærere. Elevene hadde ulik språkbakgrunn; noen av dem hadde levd mesteparten av livet i Norge, andre var sent ankomne og hadde gått mindre enn to år i norsk skole da dataene ble samlet inn.

Vi valgte å bruke ulike datakilder, og dataene omfatter semistrukturerte intervjuer med skoleledere og lærere ved de tre skolene, feltnotater fra kartleggingssituasjoner der lærer og elev samhandlet og notater fra klasseromsobservasjoner. Lærerne ga oss også kopier av noen utfylte språkbiografier og kartleggingsskjemaer. Fordelen ved å bruke semistrukturerte intervjuer er at informantene fokuserer på samme nøkkelspørsmål samtidig som formen er så åpen at de kan få gitt uttrykk for flere sider ved sine erfaringer og vurderinger. Intervjuene med skolelederne fokuserte på rutinene og organiseringen av opplæringen for språklige minoriteter og på deres vurdering av det aktuelle kartleggingsverktøyet sammenlignet med tester og andre vurderingsverktøy. I intervjuene med lærerne fokuserte vi på deres personlige erfaringer med bruken av verktøyet, om de involverte elevene i kartleggingen og om de brukte kartleggingsresultatene i den videre planleggingen av undervisningen. Gjennom bruk av en kasusstudie med ulike datakilder kom vi tett på praksis. Skolelederes og læreres vurderinger kunne ses i sammenheng, og gjennom observasjoner kunne vi selv danne oss et bilde av hvordan kartleggingen fungerte. Denne artikkelen er i hovedsak basert på intervjudataene, men vi trekker også i noen grad inn observasjoner av kartleggingssitusjoner og undervisning.

Etter to år ønsket vi å finne ut om skolene fortsatt brukte kartleggingsverktøyet og om de eventuelt hadde endret bruken og/eller oppfatningen av verktøyet. For å få svar på dette sendte vi et spørreskjema til skolelederne. Svarene viste at skolene brukte materiellet som tidligere. For å få mer kunnskap om bruken av Kartleggingsmateriell. Språkkompetanse i grunnleggende norsk for språklige minoriteter og for å kunne sammenlikne funn fra de tre kasusskolene med praksis ved andre skoler, ble det også gjennomført en spørreundersøkelse i mars 2013. Utvalget for undersøkelsen var ikke tilfeldig, men var det som kalles fokusskoler for Nasjonalt senter for flerkulturell opplæring (NAFO 2013). Dette er skoler som arbeider for å vektlegge flerkulturelle perspektiver. For grunnskolen finnes det slike fokusskoler i alle fylker i Norge, til sammen 32 skoler. Ved å velge fokusskoler sikret vi en geografisk spredning 
i utvalget. 22 av skolene svarte på undersøkelsen. De representerer 21 ulike kommuner og 16 fylker.

Spørreundersøkelsen dreide seg om rutiner for kartlegging av språkkompetanse, hvordan skolene brukte kartleggingsmateriellet og om fordeler og ulemper ved dette materiellet. Skolene ble også bedt om å vurdere i hvilken grad kartleggingsverktøyet kunne bidra til underveisvurdering av elever og om det var et hjelpemiddel for å tilpasse og planlegge undervisningen.

\section{Resultater av kasusundersøkelsen}

\section{Tre skoler, tre tilnærminger til kartlegging av andrespråksferdigheter}

De tre skolene i hovedstudien hadde et noe ulikt utgangspunkt for å ta i bruk kartleggingsverktøyet. I det følgende vil vi presentere data fra skolene før vi avslutter med å sammenligne hvordan de brukte og evaluerte kartleggingsverktøyet.

\section{Skole A}

Skole A ligger i en kommune som året før vi startet vår undersøkelse hadde bestemt at alle skolene i kommunen skulle bruke kartleggingsverktøyet før det ble fattet beslutning om at en elev skulle ha særskilt språkundervisning. Kartleggingen måtte gjennomføres i løpet av svært kort tid. Alle kontaktlærerne gjennomførte kartlegging av de aktuelle elevene i sin klasse, men på grunn av kort tidsfrist og liten kompetanse i å vurdere andrespråksferdigheter var de skeptiske og fant det vanskelig å bruke verktøyet. Bruken deres av verktøyet var i hovedsak summativ og formålet først og fremst administrativt. Det følgende skoleåret bestemte skolelederen at kartleggingen bare skulle gjennomføres av to av de ansatte som hadde spesiell kompetanse og erfaring innenfor feltet, én av disse lærerne var andrespråkslærer. De to lærerne skulle gi tilbakemeldinger til de andre lærere slik at de kunne tilpasse undervisningen sin i tråd med hva kartleggingen hadde vist.

Da skolelederen summerte opp skolens erfaringer, sa hun at de etter endringen av rutiner var positive til bruk av kartleggingsverktøyet. Hun la spesielt vekt på at verktøyet hadde gjort dem mer bevisst på mange aspekter ved andrespråksundervisning og -læring og på betydningen av å ha kvalifiserte lærere på dette området. Resultatene fra kartleggingen ville bli brukt som hjelp til å organisere opplæringen det følgende skoleåret, eller som informasjon for nye lærere hvis elever byttet skole eller klasse.

Læreren vi intervjuet, brukte kartleggingsmateriellet som et pedagogisk hjelpemiddel og rapporterte at det hjalp henne til å tilpasse opplæringen ut fra behovet til de minoritetsspråklige elevene. Hun involverte ikke elevene direkte i kartleggingen, hun bare snakket med dem om det som hun mente det var nødvendig for dem å fokusere på i språklæringen. Hun hadde ikke drøftet 
vurderingene med foreldrene, men da hun fikk spørsmål om dette, syntes hun det ville være en god ide å gjøre det.

\section{Skole B}

Skole B var i en lignende situasjon som skole A i den forstand at det også i denne kommunen var obligatorisk å bruke kartleggingsverktøyet når skoler skulle ta avgjørelser om andrespråksundervisning. Det viste seg at skole B hadde funnet verktøyet for omfattende, og den ansvarlige læreren hadde derfor endret på originalen. Den nye versjonen inneholdt færre kompetansemål, og elevene ble bare vurdert ut fra en skala med kan / kan ikke - ikke med samme gradering som i det originale dokumentet. Andre viktige deler av verktøyet som var utelatt, var språkbiografien og de to hovedområdene språklcering og språk og kultur.

Kartleggingen av elevene må derfor anses å være mindre i tråd med det som opprinnelig var hensikten. Ved å utelate språkbiografien fikk ikke skolen informasjon om elevens flerspråklige kompetanse, og ved å bruke en skala med bare kan og kan ikke mistet de språkutviklingsperspektivet. En kan derfor konkludere med at skolen ikke vurderte sine andrespråkselever med det verktøyet som var utviklet og anbefalt av Utdanningsdirektoratet. Skolelederen uttrykte imidlertid at hun var fornøyd med kartleggingsprosedyrene, spesielt med hvordan de brukte verktøyet på en summativ måte for å ta avgjørelser om særskilt norskopplæring. I løpet av den perioden vi gjennomførte vår undersøkelse, skjedde det imidlertid en forandring som gjaldt skalaen for måloppnåelse. Skolen besluttet å inkludere kan med litt hjelp sammen med vurderingene kan og kan ikke for å få bedre inntrykk av elevens utvikling.

Bare andrespråkslæreren syntes å bruke kartleggingen formativt. Hun inkluderte elevene i kartleggingsprosedyrene og diskuterte framtidige mål med dem, og fulgte dermed intensjonene bak det opprinnelige verktøyet og retningslinjene for bruken. Denne læreren hadde deltatt på etterutdanningskurs om bruk av kartleggingsverktøyet for grunnleggende norsk, mens den andre læreren vi intervjuet på skole $\mathrm{B}$ virket generelt mer ukjent med vurdering av andrespråk.

\section{Skole C}

Den siste av skolene i vår studie, skole $\mathrm{C}$, skiller seg på mange måter fra de andre to. For det første ved at lærerne selv hadde tatt beslutningen om å bruke verktøyet uten press eller veiledning fra kommunen eller skolelederne. For det andre ved at andrespråkslærerne var organisert i et spesielt team, undervisningen i norsk som andrespråk utgjorde hoveddelen av stillingen deres. Dette hadde sammenheng med at det var mange nykommere blant de språklige minoritetselevene ved skolen. For disse lærerne hadde verktøyet primært et pedagogisk formål. Vurdering av elevene var en del av det daglige arbeidet, og ved hjelp av kartleggingsverktøyet satte de nye mål for elevene ut fra læreplanen i grunnleggende norsk. De eldre elevene ble regelmessig inkludert i kartleggings- 
prosedyrene, og den endelige vurderingen ble diskutert med klasselærerne. Verktøyet ble også brukt ved foreldrekonferanser for å gi informasjon om elevens resultater.

Den skolelederen som hadde minoritetsspråklige elever som sitt ansvarsområde, mente at bruken av kartleggingsverktøyet hadde mange fordeler sammenlignet med tidligere praksis. Verktøyet var mer systematisk, sa hun. Det var også lett å tilpasse det i det daglige arbeidet, og det ga bedre grunnlag for å formidle elevenes ferdigheter og språknivå både til andre lærere og til foreldrene. Det var også nyttig for nye lærere dersom elevene flyttet til andre skoler.

\section{De tre skolene i et sammenliknende perspektiv}

I undersøkelsen vår fant vi flere likheter i overordnede prosedyrer, men også at andrespråksferdigheter ble vurdert på noe ulik måte fra en skole til en annen på tross av at det felles utgangspunktet de hadde i kartleggingsverktøyet for grunnleggende norsk. Alle skolene måtte fullføre kartleggingen innen en bestemt dato (som varierte fra en kommune til en annen) for å kunne innrapportere antallet elever som hadde behov for særskilt norskopplæring. Dette var nødvendig for at skolene skulle få tilleggsressurser for å gi andrespråksundervisning til de aktuelle elevene. Et annet fellestrekk var at alle lærerne baserte deler av kartleggingen på observasjoner og kunnskaper om elevene sine som de fikk gjennom ordinært klasseromsarbeid, enten i fellesundervisning i stor klasse eller i mindre grupper med andrespråksinnlærere. Mange av målene i kartleggingsverktøyet dreier seg om aktiviteter som er inkludert i ordinær språkopplæring. En lærer vil derfor uten vanskeligheter kunne vurdere en elevs ferdigheter innenfor disse aktivitetene etter en viss tid. De fleste lærerne diskuterte også vurderingene med elevens lærere $\mathrm{i}$ andre fag. På skole $\mathrm{C}$ var det en uttalt strategi, både for å gi tilpasset undervisning og for å få tilstrekkelig informasjon om elevene, å bruke kompetansemålene som grunnlag når de planla framtidig undervisning slik at elevene kunne få vist sin kompetanse i ordinære klassesituasjoner. Slik ble kartleggingen del av vanlig skolearbeid, og elevene kunne slippe å føle det presset som mer formelle kartleggingssituasjoner kan gi. Våre observasjoner ga oss flere eksempler på denne måten å kartlegge elevene på.

Ved skole B og C ble de eldre elevene involvert i kartleggingsprosedyrene. Lærerne diskuterte de forskjellige "eleven kan"-utsagnene med elevene og lot dem være med på å vurdere om de kunne gjøre de forskjellige oppgavene med noe hjelp eller uten hjelp. Læreren på skole B fremhevet at elevene likte å bli involvert i dette, og at diskusjonene de hadde om framtidige mål, motiverte dem og fikk dem til å forstå at grunnleggende norsk var et fag på linje med andre skolefag.

På skole A hvor de hadde besluttet å bruke bare to erfarne lærere til å foreta kartleggingen, arrangerte de mer formaliserte situasjoner for å vurdere elevens vokabular, lesekompetanse og muntlige kompetanse som supplement til den 
vurderingen som klasselæreren kunne foreta. Som nevnt tidligere, diskuterer både McKay (2006) og Daugaard, (2009) utfordringer forbundet med å vurdere andrespråkskompetanse. I de situasjonene vi observerte, så det ut til at lærerne hadde tatt hensyn til disse vanskelighetene gjennom måten kartleggingen var organisert på, og ved at de skapte positive situasjoner når de fikk elevene til å utføre ulike oppgaver. Det virket også som elevene gjerne ville gjøre sitt beste (jf. Palm \& Ryen, 2011). Det er likevel en fare for at barn kan bli feilbedømt i slike situasjoner. Tause elever kan være ute av stand til å få vist hva de virkelig kan i slike mer formelle situasjoner med voksne, mens aktive pratsomme elever kan bli overvurdert og dermed ikke får den tilpassingen i opplæringen som de kunne ha behov for.

Felles for skolene var at alle skolelederne uttrykte at bruken av kartleggingsverktøyet hadde økt bevisstheten deres om behovet for at lærere hadde kompetanse i norsk som andrespråk. De så også betydningen av at det var de mest erfarne lærerne som hadde ansvar for undervisningen av andrespråkselevene.

Som nevnt tidligere i artikkelen, har norske skoler tradisjonelt brukt mange ulike tester og selvlaget materiell for å vurdere andrespråkselevene. Ulike typer materiell hadde også vært i bruk ved de tre skolene i vår studie. Men praksis var endret etter innføringen av kartleggingsverktøyet for grunnleggende norsk, og en av skolelederne sa at bruken av dette verktøyet hadde fått henne til å se svakhetene ved det materiellet de hadde brukt tidligere.

\section{Resultater av spørreskjemaundersøkelsen}

Som vi har redegjort for tidligere, sendte vi i mars 2013 et spørreskjema til noen utvalgte skoler. Av de 22 skolene som besvarte skjemaet, er det kun én skole som ikke bruker kartleggingsmateriellet, to skoler oppgir at det brukes noe, én skole bruker det bare med elever i innføringsklasse, mens 17 skoler bruker materiellet fast. Alle bruker det i forbindelse med enkeltvedtak etter opplæringslovens § 2-8. Dette er i tråd med én av intensjonene med kartleggingsmateriellet, nemlig den summative bruken, og samsvarer her med de tre kasusskolenes bruk av materiellet.

Svarene som ble gitt når det gjaldt vurderinger av materiellet, var noe sprikende. Ulemper som hyppigst trekkes fram, er at verktøyet er tidkrevende å bruke og at kartleggingen blir mye basert på skjønn og subjektive vurderinger hos læreren. Når det gjelder fordeler, er det særlig den konkrete dokumentasjonen som kartleggingen innebærer som anses som positivt, for da kan både foresatte få informasjon, andre lærere som skal arbeide med eleven kan bli orientert, og en ny skole kan informeres ved eventuell overføring. Flere trekker fram at en fordel ved kartleggingen er at den er til hjelp i underveisvurderingen av elevene, og at de konkrete kompetanseområdene som er beskrevet, gir over- 
sikt over hva eleven kan og ikke kan. Dette gir hjelp til å differensiere undervisningen. Utsagn fra skolene samsvarer godt med det både skoleledere og lærere på de tre kasusskolene ga uttrykk for.

\section{Vurdering av andrespråkskompetanse - avsluttende drøfting}

Som vist i artikkelen, får lærerne gjennom kartleggingsverktøyet for grunnleggende norsk tilbud om et verktøy som kan hjelpe dem til å se den enkelte elevs styrker og svakheter. Ifølge mange av våre informanter har verktøyet fått dem til å reflektere over elevens ulike ferdigheter og hvor hun eller han er i læringsprosessen.

I kasusstudien erfarte vi dessuten at bruken av et verktøy som var laget for å vurdere andrespråkskompetanse, også hjalp skolen og lærerne til å endre praksis slik at andrespråksopplæringen ble mer systematisk og bedre ved at de tok som utgangspunkt at elevene hadde sine grunnleggende språkferdigheter i et annet språk enn norsk. Det hadde også en positiv washback-effekt ved at opplæringen ble endret slik at det ble undervist i flere språklige aspekter enn tidligere. Sentralt er at det ble lagt mye mer vekt på muntlig kompetanse, både lytting og tale, og det ble erkjent at læring av vokabular er avgjørende for å utvikle skriftspråklige ferdigheter.

Kartleggingsverktøyet er i hovedsak enspråklig. Det er laget for å vurdere elevens ferdigheter og progresjon i norsk gjennom varierte målbeskrivelser for lytting, tale, lesing og skriving. Men verktøyet og læreplanen for elever fra språklige minoriteter tar også hensyn til elevens flerspråklige kompetanse. Et godt utgangspunkt for tilpasset undervisning og for anerkjennelse av elevens tidligere kunnskaper er språkbiografien slik vi har påpekt. Gjennom språkbiografien kan en tilkjennegi at elevens bakgrunn og førstespråk tillegges verdi, og læreren får innsikter hun kan bygge på i undervisningen.

Et flerspråklig perspektiv blir også til en viss grad ivaretatt i kompetansemålene, spesielt innenfor hovedområdet språklcering der det for eksempel heter at eleven "kan bruke sine egne erfaringer til å snakke om likheter og forskjeller mellom norsk og morsmålet sitt" (nivå 2) og "eleven kan identifisere noen likheter og forskjeller mellom norsk og eget morsmål og kan utnytte dette i egen språklæring" (nivå 3). Det er derfor uheldig om skoler velger bort denne delen av kartleggingsverktøyet, slik skole B i undersøkelsen vår hadde valgt å gjøre.

Som vist, er kartleggingsverktøyet kriteriebasert, det vil si at elevene blir sammenlignet med nivåer for språkoppnåelse som blir uttrykt gjennom ulike kompetansemål. Det er noen problemer forbundet med et kriteriebasert kartleggingsverktøy. Nivåbeskrivelsen vil kunne bli basert på delvis subjektive antagelser. Flere av skolene vi var i kontakt med, uttrykte at de syntes det kunne være vanskelig å nivåplassere elevene ved hjelp av kartleggingsverktøyet. Dette kan imidlertid være et mindre problem hvis lærere samarbeider, og elevenes 
kompetanse blir vurdert ikke bare av andrespråkslæreren, men også av andre faglærere, slik det ble gjennomført spesielt ved skole C i vår studie. Dette var den kasusskolen som på eget initiativ tok kartleggingsverktøyet i bruk så snart det forelå. De fant at det passet med den kommunikative tilnærmingen de hadde i opplæringen av andrespråkselever. Skolen la stor vekt på samhandling og tett oppfølging og tilbakemelding for den enkelte elev. Flere av lærerne hadde også andrespråkskompetanse. Det ser ut til at slike faktorer fører til at lærere stoler på eget skjønn, og at det da blir mindre behov for rigide tester som poengsetter elever. Ulike prøver kan være et supplement til kartlegging. Normbaserte tester oppfattes imidlertid av mange som mer objektive og brukes ofte ukritisk. Daglignorsk-prøven som vi har omtalt tidligere, er et eksempel på en test som er lett å administrere og skåre, men som er langt mindre troverdig enn en bredskalavurdering ut fra godt faglig skjønn.

Da kartleggingsverktøyet ble introdusert i 2007, var det mange kommuner, inkludert to av de tre i vår hovedundersøkelse, som ga lærere pålegg om å bruke verktøyet før de tok en avgjørelse om særskilt språkopplæring. Som en følge av dette fikk mange skoler det inntrykket at innføringen av verktøyet bare hadde administrative formål og at kartleggingen måtte gjennomføres innen svært korte tidsfrister. Dette kan forklare hvorfor skole A og B i vår undersøkelse i første omgang syntes at det var så omfattende å bruke verktøyet. Som vist, besluttet skole $\mathrm{A}$ at bare to erfarne lærere skulle være ansvarlige for kartleggingen i planlagte vurderingssituasjoner. Skole B laget en forenklet versjon av verktøyet. Men ettersom de fikk mer erfaring, endret skolene praksis i retning av mer pedagogisk bruk av verktøyet. Etter en tid brukte også alle lærerne verktøyet i planlegging av videre opplæring. Også blant informantene i spørreundersøkelsen var det noen som mente at det tok for lang tid å bruke verktøyet, dette kan for noens del ha sammenheng med at de slik skolene A og B gjorde i startfasen, ser det som et verktøy for summativ vurdering der en skal sjekke ut punktene på et bestemt tidspunkt.

På politisk og administrativt nivå er det et kritisk punkt at signalene er uklare. Myndighetene fastslår i opplæringsloven at elever har rett til særskilt språkopplæring og at skolene har plikt til å vurdere elevenes språkferdigheter, før de tar avgjørelse om slik opplæring. Samtidig er det opp til den enkelte kommune eller hver enkelt skole å avgjøre hva slags kartleggingsmateriell de skal bruke. Det står også skolene fritt å velge om de vil bruke læreplanen i grunnleggende norsk for språklige minoriteter eller om en lokalt heller skal tilpasse undervisningen til den ordinære norskplanen. Denne uklarheten er spesielt problematisk siden lærere og skoler ofte mangler kompetanse både i andrespråksundervisning, i vurdering og i hvordan de skal fortolke resultatene av vurderingen. Som understreket i OECD Reviews of Migrant Education Norway (Taguma m.fl., 2009, s.27) er det behov for å oppmuntre både grunnskoler og videregående skoler til å ta mer hensyn til det økende språklige og kulturelle mangfoldet blant elevene, og de anbefaler sterkt at skolemyndighetene 
utformer lærerutdanning og etterutdanning "so that all teachers - not only language teachers - will be able to individualize students learning by carrying out formative assessment in classroom, teaching second language learners and by incorporating immigrant students' different cultures, knowledge, and previous experiences into teaching".

\section{Litteratur}

Alderson, J.C. m.fl. (1995). Language Test Construction and Evaluation. Cambridge: Cambridge University Press.

Arbeid med ord (2014). Hentet 07.04.14 fra http://www.arbeidmedord.no/produkter/norsk/lese-og-skrivekurs/daglignorsk-proven/

Backmann, K., Haug, P., Myklebust R. (2010). Med rett til å prestere. I Elstad, E. \& Sivesind, K. (red.), PISA - sannheten om skolen? Oslo: Universitetsforlaget.

Baker, C. (2006). Foundation of Bilingual Education and Bilingualism. Bristol: Multilingual Matters.

Council of Europe (udatert): Common European Framework of References for Languages: Learning, teaching, assessment. Hentet 07.04.14 fra http://www.coe.int/t/dg4/linguistic/Cadre1_en.asp

Council of Europe (2011): European Language Portfolio (ELP). Hentet 07.04.14 fra http://www.coe.int/t/dg4/education/elp/

Danbolt, A.M.V. m.fl., (2010). Oppleringstilbudet til minoritetsspråklige innen barnehage og grunnopplcering. Rapport 01/2010. Notodden: Telemarkforsking.

Daugaard, L.M. (2009). Et interaktionelt perspektiv på evaluering av børns sprog - om at skabe betydning i evalueringssamtaler. I L. Holm \& P.H. Laursen, En bog om sprog - $i$ daginstitusjoner. Analyser af sproglig praksis. København: Danmarks Pædagogiske Universitetsforlag.

Figueras, N. \& al (2005). Relating examinations to the Common European Framework: a manual. I Language Testing. Hentet 07.04.14 fra http://li.sagepub.com/content/22/3/261.full.pdf+html

Fremmedspråksenteret (udatert): Europeisk språkperm 13-18 år. Hentet 07.04.14 fra http://www.fremmedspraksenteret.no/index.php?ID $=10110$

Forvaltningsloven (§ 2) Hentet fra http://www.lovdata.no/all/hl-19670210-000.html

Hauge, A.-M. \& Ryen, E. (1992) Plasseringstest for språklige minoriteter. Ny praksis i norsk skole? I Norsk skoleblad (6).

Holm, L. \& Laursen, P. (2010) Dansk som andetsprog. Pcedagogiske og didaktiske perspektiver. Dansklærerforeningens forlag.

Hvistendahl, R. \& Roe, A. (2004). The literacy achievement of Norwegian Minority Students. I Scandinavian Journal of Educational Research. 48(3), July 2004.

Hvistendahl, R. \& Roe, A. (2009). Leseprestasjoner, lesevaner og holdninger til lesing blant elever fra språklige minoriteter. I Norsk pedagogisk tidsskrift 4, 2009.

Hyland, K. (2003). Second Language Writing. Cambridge: Cambridge University Press.

Leung, C. (red.) (2005). Classroom Teacher Assessment of Second Language Development: Construct as Practice. I Hinkel, E. (Red), Handbook of Research in Second Language Teaching and Learning. Mahwah, New Jersey/London: Lawrence Erlbaum Associates.

Loona, S. (1995). Tospråklighetsprøven (TOSP), stensilutgave og pdf-fil (tilgjengelig ved henvendelse til forfatteren).

McKay, P. (2006). Assessing Young Language Learners. Cambridge: Cambridge University Press.

McNamara, T. (2000). Language Testing. Oxford University Press. 
Monsrud, M.-B. (2012). Svake andrespråksferdigheter eller spesialpedagogiske behov? I

K.M. Bjerkan, M.-B. Monsrud \& A.C. Thurmann-Moe, Ordforråd hos flerspråklige barn. Pedagogiske og spesialpedagogiske utfordringer (s.103-128). Oslo: Gyldendal akademisk.

NAFO (2013). Hentet 27.02.13 fra http://danielg.hioa.no:82/Om-HiOA/NAFO/Fokusvirksomheter

Opplæringslova: hentet fra http://www.lovdata.no/all/hl-19670210-000.html

Oslo kommune, Utdanningsetaten: hentet 07.04.14 fra http://www.utdanningsetaten.oslo.kommune.no/category.php?categoryID=63893

Ot.prop. nr 55 (2008-2009) Om lov om endringar i oppleeringslova og privatskolelova. Oslo: Kunnskapsdepartementet.

Palm, K. \& Ryen, E. (2011). Kartlegging av ferdigheter på andrespråket. I J. Smidt, E. S. Tønnessen \& B. Aamotsbakken (Red.), Tekst og tegn: lesing, skriving og multimodalitet $i$ skole og samfunn (s. 255-272). Trondheim: Tapir akademisk forlag.

Rambøll Management (2006). Evaluering av praktiseringen av norsk som andrespråk forspråklige minoriteter i grunnskolen. Utdanningsdirektoratet: hentet frå http://www.udir.no/upload/Rapporter/Evaluering_av_Norsk_som_2_sprak.pdf

Shohamy, E. (2011). Assessing multilingual competencies: Adopting construct valid assessment policies. The Modern Language Journal. 3-2011. Hentet 27.02.13 fra: http://onlinelibrary.wiley.com/enhanced/doi/10.1111/j.1540-4781.2011.01210.x/

Stokke, K.H., Throndsen, I., Lie, S. \& Dale E.L. (2008). Evaluering av vurdering for læring. Institutt for lærerutdanning og skoleutvikling. http://www.udir.no/Upload/Rapporter/2008/5/Evaluering_laring.pdf?epslanguage=no

Utdanningsdirektoratet (2007). Kartleggingsmateriell. Språkkompetanse I grunnleggende norsk. Hentet 07.04.14 fra http://www.udir.no/upload/kartleggingsprover/UDIR_kartleggingsmateriell_bm_301007. pdf

Utdanningsdirektoratet a (udatert): Læreplan i grunnleggende norsk for språklige minoriteter. Hentet fra http://www.udir.no/kl06/NOR7-01/

Utdanningsdirektoratet b (udatert): Europeisk språkperm for voksne innvandrere. Hentet 07.04.14 fra http://www.udir.no/Upload/Verktoy/5/UDIR_Sprakperm_Voksne_web.pdf?epslanguage= $\underline{\text { no }}$

Utdanningsdirektoratet: Nasjonale prøver. Rettleiing og retningslinjer. Hentet fra http://www.udir.no/Vurdering/Nasjonale-prover/Rettleiing-og-retningslinjer-nasjonaleprover/2-for-gjennomforinga/

Taguma m.fl. (2009). OECD Reviews of Migrant Education Norway. Hentet fra http://www.oecd.org/norway/43901573.pdf

van Lier, L. (2004). The Ecology and Semiotics of Language Learning. A Sociocultural Perspective. Amsterdam: Kluwer Academic Publishers.

Vibe, N.,Evensen, M. \& Hovdhaugen, E. (2009). Spørsmål til Skole-Norge. Tabellrapport fra Utdanningsdirektoratets spørreundersøkelser blant skoler og skoleeiere våren 2009. Rapport nr. 33 2009. Oslo: NIFU Step

Wagner, Å.K.H (2004). Hvordan leser minoritetsspråklige elever i Norge? En studie av minoritetsspråklige og majoritetsspråklige 10-åringers leseresultater og bakgrunnsfaktorer i den norske delen av PIRLS 2001. Stavanger: Nasjonalt senter for leseopplæring og leseforskning. 